\title{
Postinternet Marketing: For a Philosophy and Art of Online Marketing
}

\author{
Václav Janoščík ${ }^{1}$ \\ ${ }^{1}$ Academy of Arts, Architecture and Design in Prague \\ Náměstí Jana Palacha 80, 11693 Prague 1 \\ Czech Republic \\ vaclav.janoscik@vsup.cz
}

\begin{abstract}
While we are living in rapidly changing environment driven by the online services, marketing has been rather reluctant in serious apprehending of these consequences. We do not aim to analyse this complex delay that we call conceptual jetlag here. (Conceptual consciousness of marketing is far behind the velocity of the plane online services.) Rather we try to establish certain switchback that is driven by concept of philosophy by Gilles Deleuze and Félix Guattari and the artistic notion of postinternet. By these means we aim at unveiling the general drive of marketing: The product (take Photoshop as an instance) is meant not only to satisfy our needs and desires. It is creates them. This basic assumption of marketing and the dominance of online environment can elucidate each other since the "fluid ontology" of virtual environment consists precisely in the possibility of being formed by the will of its users.
\end{abstract}

Keywords: Marketing, Philosophy, Art, Postinternet, Deleuze, Jobs. 


\section{Introduction}

This article tends to refresh overall discussion about marketing by connecting it to the philosophical and postinternet discourse. By such train of thought I mean to explore possible interdisciplinary and new interpretive ground for theoretical background of marketing. Thus it forms rather newly defined field for further research and considerations. I aim at nothing more than a meeting that proceeds through three moments (postinternet, philosophy, marketing) and at articulating prospectives of their mutual dialog.

\section{First moment: the Postinternet}

"What is even more interesting is the way in which people are starting to make what I've called "Post-Internet" (...) I think it's important to address the impacts of the internet on culture at large, and this can be done well on networks but can and should also exist offline."

This is citation from interview (Debatty, 2008) with Marisa Olson.

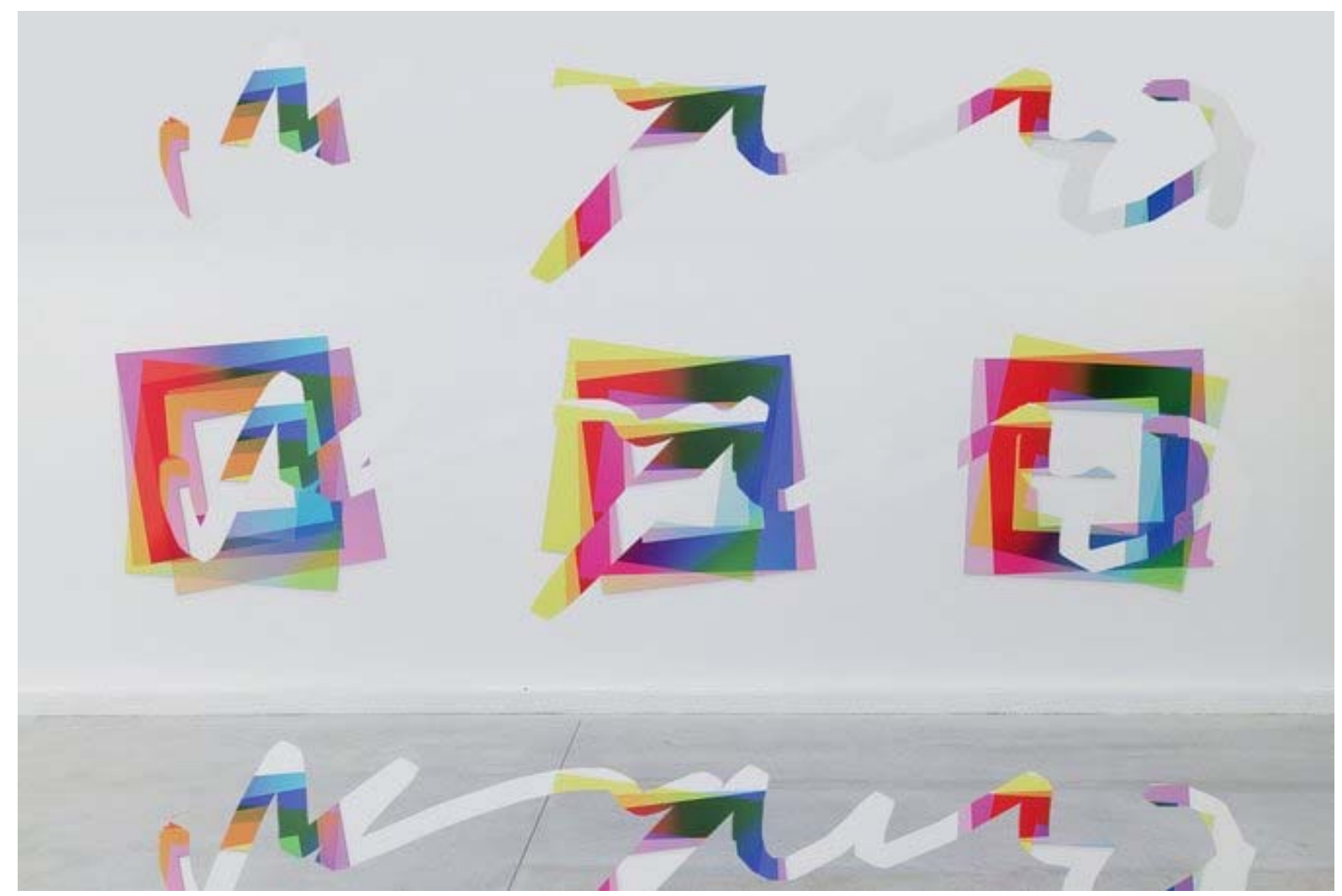

Fig. 1. Artie Vierkant, Image objects, 2011 ongoing. Source (Vierkant, 2011).

Today's online environment so as marketing floods us with plethora of instantaneous images and events which will in an instant lapse into web oblivion. The notion of postinternet can help us to conceptualize this dynamic and provide us with brief moment of philosophical reflection. It was introduced in 2008 in an interview with Marisa Olson on we-make-moneynot-art.com. It divides the net-based experience from its influence on general culture. "Less a novelty and more a banality." (McHugh, 2011) Of course it grasps primarily the practice of art but it assumes rather general stance towards the culture at large. Artist so as other users shifted from first excitement about the possibilities of net based and presumably non- 
hierarchical environment to more cynical reflection of resulting dominant forms of interaction.

Marketing then is one of these modes ruling contemporary web environment. As such it also cannot just exploit the web environment and apply its former strategies to this new field. It must reflect the overall impact the Internet has on culture at large and accommodate its assumptions according to this "postinternet" condition. In other words, the term "postinternet" suggests that the focus of a good deal of artistic and critical discourse has shifted from "internet culture" as a discrete entity to the reconfiguration of all culture by the internet, or by internet-enabled neoliberal capitalism. (Connor, 2013)

Thus though art and marketing are intuitively conceived of as mutually exclusive fields we are less assured of their contrast precisely because of their online presence. We can take elusive yet brutally actual Dismagazine ${ }^{1}$ and their stock image database disimages as penultimate example of such trend. Although the encounter of those two spheres within postinternet is somehow self-evident, their subsequent theories are not and perhaps cannot catch the train of their rapid development. From the art related side we are flooded by intentionally fragmentarized views while marketing is satisfied with methodological selfaffirmation. Here possible philosophical perspective comes in question.

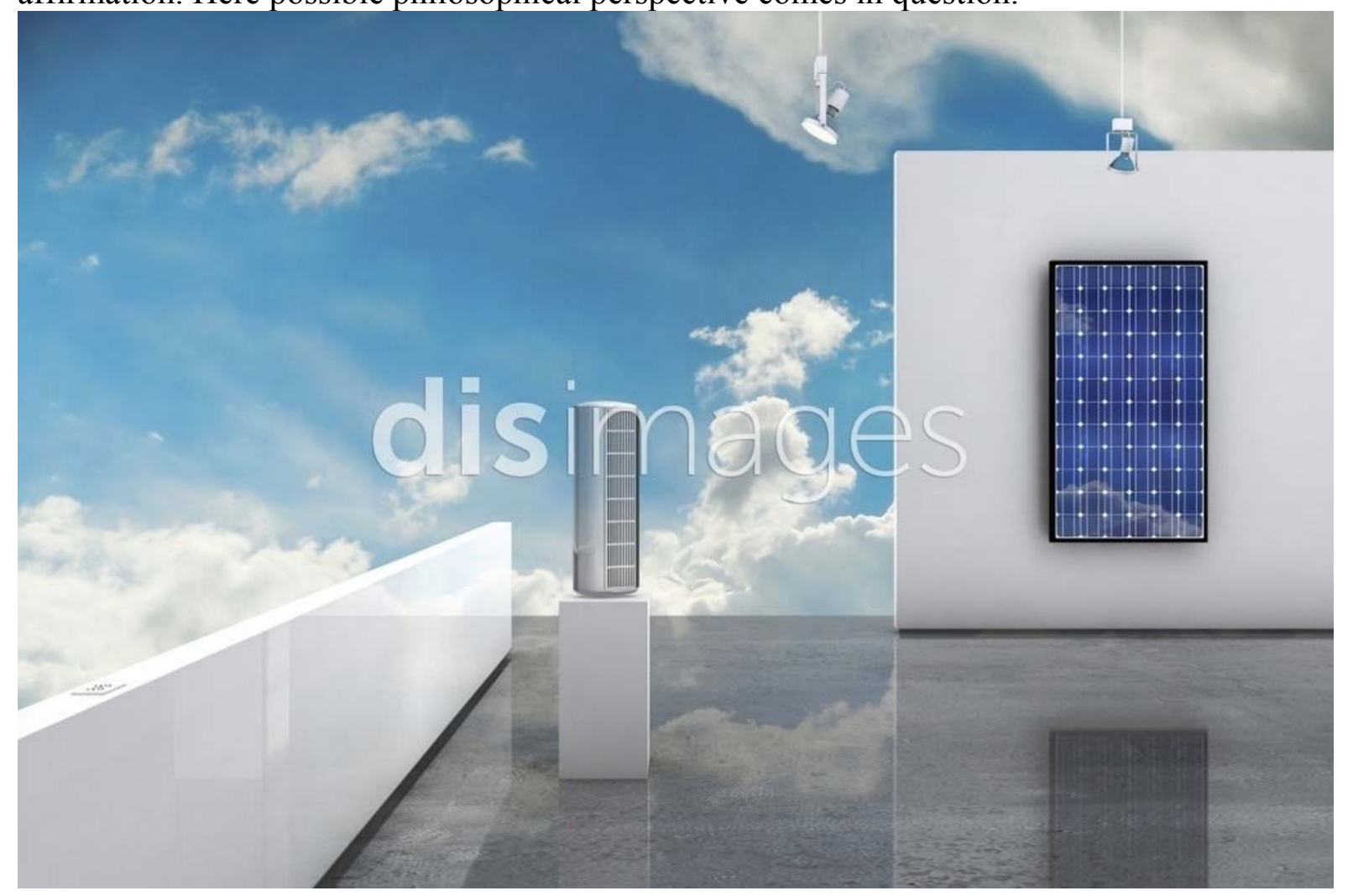

Fig. 2. DISimages may be used for art, exhibition, editorial, personal, or commercial use. Source (http://disimages.com).

\section{Second moment: the Philosophy}

"In successive challenges, philosophy confronted increasingly insolent and calamitous rivals that Plato himself would never have imagined in his most comic moments. Finally, the most shameful moment came when computer

\footnotetext{
${ }^{1}$ See http://www.dismagazine.com
} 
science, marketing, design, and advertising, all the disciplines of communication, seized hold of the word concept itself and said: "This is our concern, we are the creative ones, we are the ideas men! We are the friends of it in our computers."

Gilles Deleuze and Félix Guattari (Deleuze, Guattari, 1994, p. 10)

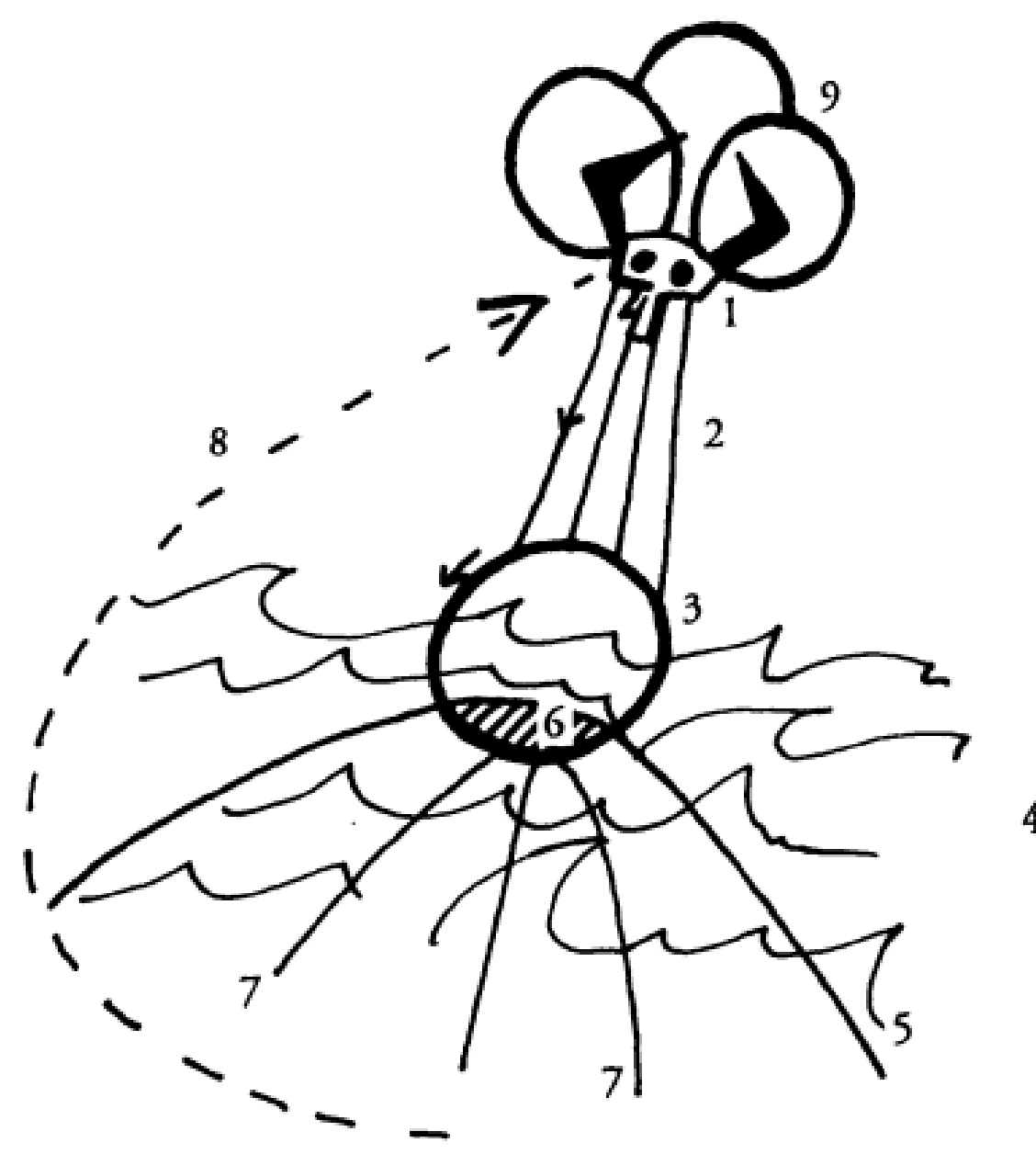

Fig. 3. Illustration to the notion of concept and level of immanence from Deleuze, Guattari: What is Philosophy? Source (Deleuze, Guattari 1994).

Philosophy and marketing along similar lines as art and marketing do have rather difficult relation. Nonetheless it is precisely this tension and even rivalry that can be considered as their common ground. We just opened seminal work by Gilles Deleuze and Félix Guattari What is philosophy? in which they propose to delimit this tension:

"Simply, the time has come for us to ask what philosophy is. We had never stopped asking this question previously, and we already had the answer, which has not changed: philosophy is the art of forming, inventing, and fabricating concepts. But the answer not only had to take note of the question, it had to determine its moment, its occasion and circumstances, its landscapes and personae, its conditions and unknowns." (Deleuze, Guattari, 1994, p. 2)

Let me underlie the two points made here in respect to marketing. Philosophy is defined as the art of forming concepts and it is precisely this perspective that connects it with marketing, 
which claims this role in today's world. Secondly philosophy as seen here by Deleuze and Guattari strives to reflect its present condition. More precisely it derives its practice from taking the present moment into the question. Then it seems to be one of its eminent tasks to respond to its actual relation or contrast with marketing as a competing sphere of concept fabrication.

Deleuze and Guattari, before they immerse themselves into nuanced structure of philosophical production, can set our path a bit further. Because among other fields claiming the role of creating concepts (computer science, marketing, design, and advertising) they highlight the marketing as at least maintaining the crucial connection of concept and events

"Marketing has preserved the idea of a certain relationship between the concept and the event. But here the concept has become the set of product displays (historical, scientific, artistic, sexual, pragmatic), and the event has become the exhibition that sets up various displays and the "exchange of ideas" it is supposed to promote. The only events are exhibitions, and the only concepts are products that can be sold." (Deleuze, Guattari, 1994, p. 10)

Within their theory concepts do not represent anyhow transcendental or permanent truths. They exist thanks to diverse conditions that elucidate the event of its appearance. In this respect marketing again plays a considerable role. It presents us with emblematic event and decisive concept. The former can be named as presentation, exposition, denoting the very act of unveiling the concept. The latter generally represents the product. As if marketing is certain theoretically quite limited system of thought that actually betray our idea of thinking by reducing concepts to products.

Philosophy then is framed by nonphilosophy. This edge, or more precisely parergon, nonetheless does not mean any rival sphere of concept fabrication. It represents the chaos from which philosophy so as marketing pull the concepts according to Deleuze and Guattari. In this process they need the nonphilsoophical sphere. This dynamic then is more visible and symptomatic in the field of marketing. It draws all its drive from our imagination. Marketing pulls concepts out of the chaos of potential desire, no matter if our longing was actually real (preexisting) or fabricated.

From this point it seems obvious that our imagination and longing stimulated by marketing concerns not only the objects themselves but also the context of values they stand for: "What is recognized is not only an object but also the values attached to the object (values play a crucial role in the distribution undertaken to make good sense)." (Deleuze, 1994, p. 135)

In a nutshell Deleuze and Guattari provide us with ground on which philosophical information of marketing can be realized. In their view marketing creates concept in form of products.

\title{
4 Third moment: the Marketing
}

\author{
"Stay hungry! Stay Foolish!"
}

Steve Jobs ${ }^{2}$

Contrary to general opinion about decisive role of Steve Jobs as marketer there is little if no theoretical interest at all in his marketing. For his person might be considered as the model of such concept fabrication through marketing. His approach was based in assumption that customers do not know what they want. Then that is the role of marketing to create new concepts structuring our desires along with their commercial exploitation.

Such an approach, no matter how cynical, actually fits the process of concept fabrication fairly well. It is rooted in the idea of newness of the product. It brings us ahead of time both in

\footnotetext{
${ }^{2}$ Steve Jobs giving his famous speech at Stanford. See: https://www.youtube.com/watch?v=gO6cFMRqXqU
} 
relation to our competing marketers and general costumer imagination. Steve Jobs referred to such untimeliness by a joke from legendary hockey player Wayne Gretzky: "I skate to where the puck is going to be, not where it has been." (Block, 2007)

Moreover so called "reality-distortion field" is ascribed to his practice. That means he aimed at restructuring our comprehension of reality by conceptual and even charismatic means compelling us to believe in new possibilities ${ }^{3}$. This brings us really close to the sketched phenomenon of postinternet. In its sphere we are no longer fascinated only by the possibility of creating or manipulating concepts online - for example consumer can be also in position of brand manager, because consumers are able to create their own content related to particular brand (Christodoulides, 2009; Simmons, 2008). We are shifting our user experience from online environment back into new material reality. 3D printers can be considered an emblem of such a reverse postinternet dynamic. What represented specifically online modes of interaction - sharing, individualization of interface and services, networking - is now being realized in our physicall reality and on general cultural level.

Lev Manovich characterized virtual environment by their "fluid ontology". (Manovich, 2001, 206) That means that individual users form its very space. This cultural logic is now being transposed to our so-called physical reality and 3D printing can be considered its herald.

\footnotetext{
${ }^{3}$ See for instance:

http://www.folklore.org/StoryView.py?project=Macintosh\&story=Reality Distortion Field.txt
} 


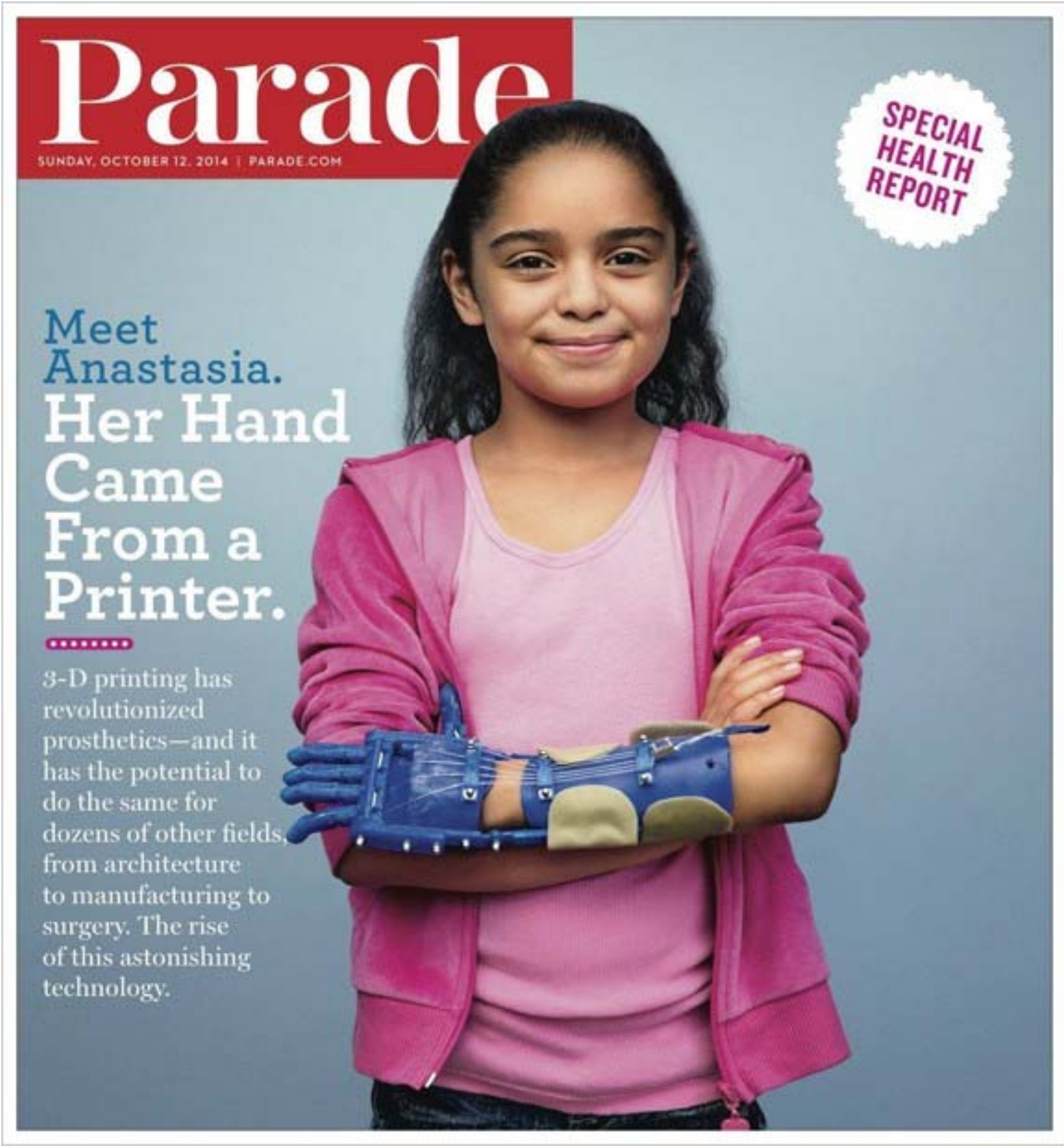

Fig. 4. Prospectives of 3D printer technology can be illustrated by its use in prosthetics, here on cover of October 12, 2014 issue of Parade.

\section{1 "Yes we can": Imagination between philosophy and marketing}

Let us brought one last instance of this marketing moment considering Jobs`s own view on marketing. When he reflected on the development of big companies like IBM, Pepsi or Xerox in particular he had seen great difference and struggle indeed between the marketers and designers. ${ }^{4} \mathrm{He}$ tells us quite simply that for instance in certain segments you have very limited possibilities of coming up with new product (Pepsi Co.) and thus the marketers are the important people for success of the company a subsequently they are being promoted and run the company at the expense of the designers. But his happened even for the technology

${ }^{4}$ For Steve Jobs giving an interview about Xerox failure: https://www.youtube.com/watch?v=1rXqD6M614 
corporation, mainly because of their monopoly market share. That means if we rule certain segment of the market we are not motivated to innovate our products, but we can rise revenues by marketing means. This can go fairly well for some companies like Pepsi, but it turned out to be disastrous for technology companies for which the product innovation is essential. Thus when Xerox became to be run by marketers it gradually lost its drive.

What is Jobs saying is basically that we need to broaden our horizon of prospective products in order to stay on top. We need to create not follow the needs of our (future) customers. Of course this particular attitude applies mainly to the biggest multinational corporations, but let us consider small businesses whose only chance to enter the contemporary market is to come up with something completely new within or to promote existing services in new markets. (Take Chinese company Alibaba as an example of such intersection of an old service with new market.) Anyway this dynamic opens up the rupture between our present concepts (products) and desired commercial utopia.

This rupture has a philosophical name - it is imagination. For instance in Kant's philosophical system it bears the key role of bridging the "thing-in-itself" (noumenon), which is generally unknowable, with our images of such things, which we nonetheless somehow have. (Oizerman, 1981; Rastovic, 2013; Kant, 1998, B103) It seems quite appropriate to interpret the marketing as spreading itself within this field of this Kantian "imagination". It creates products or images of our (supposed) desires, longings and even fears. Thus it connects the primordial chaos of potential aspiration with specific concepts or products. Let us note further that Žižek famously reactualized the concept of imagination by drawing it into discussion concerning todays (popular) culture. (Žižek, 1999)

\subsection{Conceptual jetlag: challenges of today marketing}

Nonetheless this approach is neither shared nor even dominant among other marketers. It took precisely the visionary individual to shift to new products as can by illustrated on the history of Apple Corporation and its present threshold. Marketing both in theory and practice suffers from astonishing conservatism and conceptual reproduction. From the perspective of the theoretical or methodological side consider the fact that the most know book on marketing, Kottler's Marketing Management: Analysis, Planning, and Control generally considered to be the bible of marketing. It had been originally published in 1967 and it has been used ever since as main source of conceptual information about marketing, actually in its 14th edition. The author himself admits that marketing have changed entirely and he even assumes key role of the Internet in such shift. In 1967 (Kotler, 2002, Preface):

"The Internet did not exist, nor did, for example, debit cards, smart cards, cellular phones, personal digital assistants, hypercompetition, cyberconsumers, customer equity, customer value analysis, customer relationship management, price transparency, value networks, hybrid channels, supply chain management, viral marketing, integrated marketing communication, and mobile marketing. Even if some people question the existence of a new economy, they need to acknowledge the new elements in today's marketplace."

Nonetheless Kotler and his contemporary students are still reproducing the old scheme of supply-demand, product-customer. Of course there is considerable theoretical production in the field of marketing. From my perspective nonetheless even the progressive production is not willing to step out of the conceptual framework that was developed in the very beginning of the field of marketing. Consider for instance the actual special issue of the Marketing Theory journal dedicated to the problem of service dominant logic. (Brodie, Storbacka, 2014) It might be considered progressive in terms of opening (re-actualizing) the concept of 
services. This can be further connected to the problem of online environment with reference to its recent reconceptualization as the "Internet of services" (Wahlster, 2014).

The concept of guerilla marketing ${ }^{5}$ or even broader basis of relationship marketing can be considered as a small exception among the marketing mainstream. Its example is the more valuable as it exactly evaluates the online environment not only as another channel to which old conceptual instruments (marketing mix) should be applied, but it actually exploit specificity of the online condition into new conceptual apparatus, although it originated long time before the Internet took place. (Egan, 2011)

From pragmatic or practical point of view the best example seems to me the painstaking transition of music, cinema and other media to digital distribution. Consider for instance that first mp3 players were made in late nineties (first MP3 Music Player - MPMan is from 1997) while official and legal distribution channels have been established far later. ITunes introduced its iTunes store in 2003 and for quite some time became the only unrivalled platform for purchasing music.

Similar delay took place in cinema and other media. While watching movies on desktops was possible from early nineties (Apple released its Quick Time in 1991) It took marketers almost two decades to find appropriate online distribution channel. Consider for instance that the first show, crucial television genre, made exclusively for web mediated screening is House of cards produced by Netflix in 2013. (McQuire, 2004)

Of course there were some technological and even legal issues to be solved. Nonetheless the inability or even unwillingness of marketers to create new distribution channels (new concepts in Deleuzian sense) was the main obstacle here. This dynamic still forms the development of new forms of marketing. Moreover these trains of development are still not fully aware of the change that had not only brought new means of production and distribution, but also changed the very object. Movies and music is naturally perceived in considerably new manner when tracks are being downloaded separately or on the other hands whole shows are being accessed in their entirety to name just two common options newly available.

This conceptual jetlag can be easily grasped when we consider the online environment and its challenges as a sort of threshold. Taking such an event into account would precisely mean forming the postinternet marketing. My thesis thus does not claim that there is no innovation or lack of theory itself in the field of marketing. Rather I would like to capture certain delay in its ability to reflect the online environment, certain jetlag caused from the velocity of new development.

\section{Conclusion: Trojan horse of philosophy or Jennifer in paradise}

Thus the insomnia of everlasting marketing imagination has caused its theoretical oversleeping the radical change of its very condition. The question is: Does it really need to realize its situation? Is not marketing fine with continuing the threadbare path? Is postinternet marketing as delimited above even possible? Or does it represent preferable or more efficient position? Well leave this perspective on marketers and managers themselves. Anyway our point of view as its willy-nilly consumers is (not without certain irony) different and our view of what marketing fails to capture might present a small advantage in ultimately uneven clash between advertisement industry and our online presence.

\footnotetext{
${ }^{5}$ See http://www.guerrillaonline.com
} 


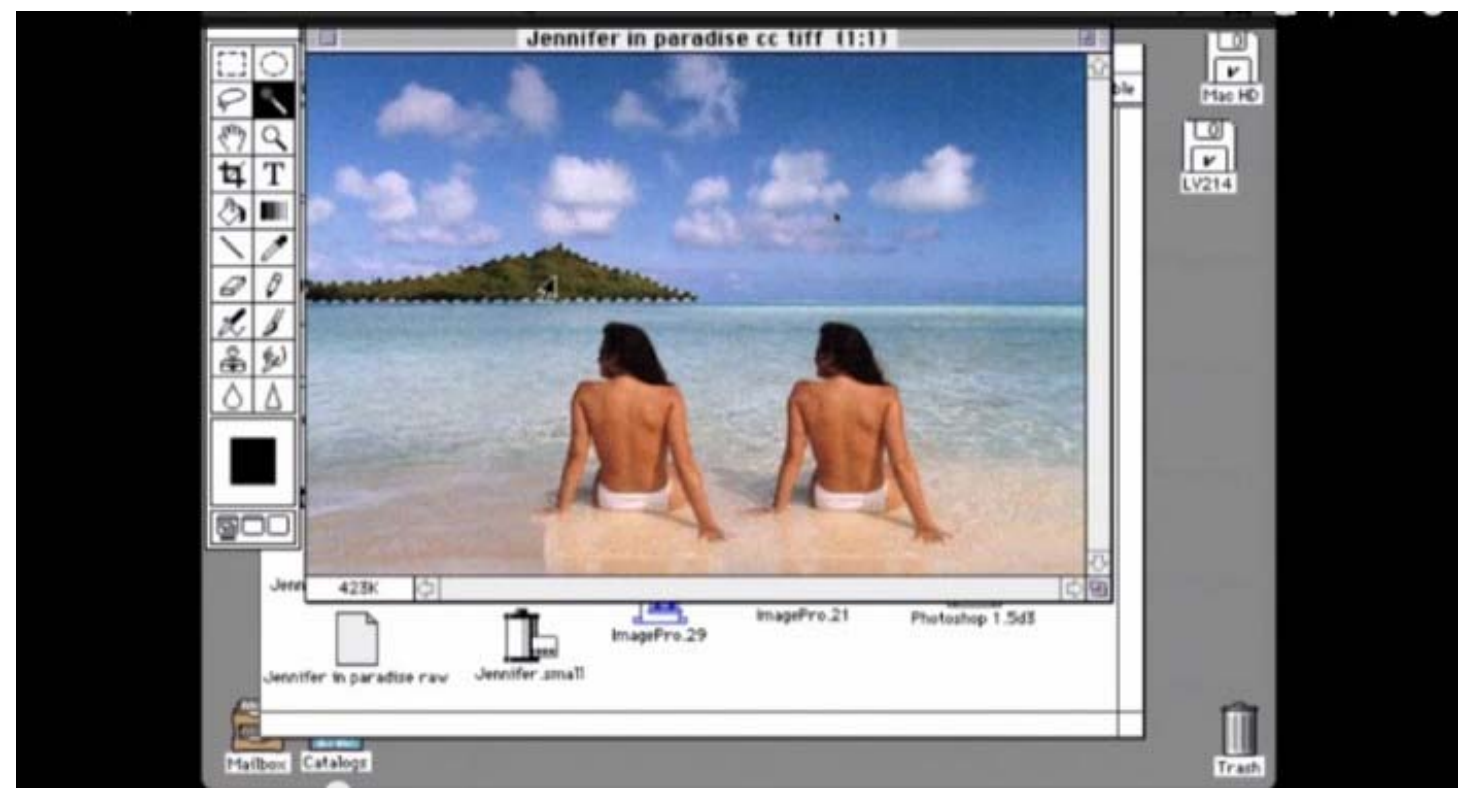

Fig. 5. Jennifer in Paradise.tif - the picture Photoshop co-creator John Knoll took of his future wife Jennifer in Bora Bora. Source (http://www.slrlounge.com).

Our present seemingly promiscuous position indeed turns out to be situated inside the field of marketing but it remains a philosophical one. From this point of view we can reflect the present condition of forming concepts along the lines of Deleuze and Guattari, thus reorient philosophy towards very unexpected relationship to marketing. It can reclaim its the question concerning its nature and contemporaneity situated on its very edge.

From the perspective of marketing we have seen considerable challenges presented both by philosophy and the online environment. It is sound that its methodological reproduction and conceptually limited reception of Internet possibilities cannot last forever. Alternatives and new forms of products will eventually emerge. Marketing will shift to its postinternet stage in order to fill our (post-online) world with brand new products satisfying our prospective longings we have never even dared to hope for.

We have an emblematic image of this drive towards new product and its promise to be not merely an artefact but also material for further imagination. This "stuff of dreams" to use phrase of curator David Elliott (Elliott, 2014) rematerializes itself in the picture of Jennifer in Paradise. The story quite complex. John Knoll took it on Bora Bora beach with his girlfriend Jennifer, just before proposing her to become his wife later on. Let me note they earned such vacation by painstaking work for Industrial Light \& Magic, Lucasfilm's special-effects company. But the real moment of the picture came later when Knoll needed an image to use as a material for further manipulation. Thus Jennifer in paradise became the first photoshoped image. Over a decade later it has been forgotten while millions of other picture were easily manipulated by the software. Since it was not available online in sufficient quality postinternet artist who calls himself Constant Dullart brought it back as a piece of art representing the story of digital cultural economies. His reappropriation might be considered essential to the story nonetheless it continues to re-actualize it in similar manner as we do here.

As such the picture represents a monument of new media imagination. Under its lascivious and kitschy exploitation of our imagination (paradise island, naked body) the very drive behind postinternet marketing unveils. The product (Photoshop) is meant not only to satisfy our needs and desires. It is creates them. 
In the online environment marketing enters not only significantly new stage of its practice, it comes closer to its very nature consisting in forming and creating our desires. Lev Manovich defines virtual space by its "fluid ontology". (Manovich, 2001, 206) That means it is created by the very behaviour of its users. In this respect Jennifer in Paradise represents the ideal of image manipulated by computer users. This logic is actually being transposed to our nondigital world or physical reality if you will.

Marketing may function well without realizing this highly underestimated or original train of thought (art-philosophy-marketing). But in order to fully expose its meaning (creating products/concepts/desires) and in order to grasp the real challenge of online environment it must undertake this conceptual adventure. Long story short, online and virtual environment pose a model case of what marketing actually is. Thesis of this article further consist in arguing that this will become visible only in certain venture into art and philosophy that are for good reason vastly more elaborate and reflective. We have just undergone one possible route in such vector, which brings us to the postinternet marketing.

\section{References}

Block, R. (2007). Live from Macworld 2007: Steve Jobs keynote. Retrieved from http://www.webcitation.org/68egMPCDQ

Brodie, R. J., Storbacka, K. (2014). Collaborative theorising about markets and marketing and service-dominant logic. Marketing Theory, 14 (3), 231-237. doi: 10.1177/1470593114534338

Christodoulides, G. (2009). Branding in the post-internet era. Marketing Theory, 9 (1), 141-144.

Connor, M. (2013, November). What's Postinternet Got to do with Net Art? Retrieved from http://rhizome.org/editorial/2013/nov/1/postinternet/

Debatty, R. (2008). Interview with Marisa Olson. Retrieved from http://we-make-money-notart.com/archives/2008/03/how-does-one-become-marisa.php

Deleuze, G., (1994). Difference and Repetition. Trans. Paul Patton. New York: Columbia University Press.

Deleuze, G., Guattari, F. (2004). Thousand Plateaus. London: A\&C Black.

Deleuze, G., Guattari, F. (1994). What is philosophy? New York: Columbia University.

Egan, J. (2011). Relationship Marketing: Exploring Relational Strategies in Marketing. New York: Pearson.

Elliott, D. (2014). Stuff of dreams. In: D. Elliott, T. Manina (Eds.), A Time for a Dream - 4th Moscow International Biennale for Young Art. Moscow: NCCA, MMOMA.

McHugh, G. (2011). Post Internet. Brescia: Link.

Kant, I., (1998). Critique of Pure Reason. Translated and edited by Paul Gyer, and Allen W. Wood. New York: Cambridge University Press.

Kotler, P. (2002) Marketing Management. New Jersey: Prentice Hall.

Manovich, L. (2001) Language of New Media. Cambrigde: MIT Press.

McQuire, S. (2004). Slow train coming? The transition to digital distribution and exhibition in cinema. Media International Australia, (110), 105-119.

Oizerman, T. I. (1981). Kant's Doctrine of the "Things in Themselves" and Noumena. Philosophy and Phenomenological Research, 41(3), 333-350.

Rastovic, M. (2013). Kant's Understanding of the Imagination in Critique of Pure Reason. E-Logos - Electronic Journal for Philosophy, 1-13.

Simmons, G. (2008). Marketing to postmodern consumers: Introducing the internet chameleon. European Journal of Marketing, 42 (3-4), 299-310.

Vierkant, A. (2011). Image Objects. Retrieved from http://artievierkant.com/imageobjects.php 
Wahlster, W., Grallert, H.-J., Wess, S., Friedrich, H., Widenka, Th. (Eds.) (2014). Towards the Internet of Services: The THESEUS Research Program. Heidelberg: Springer.

Žižek, S. (1999). The Ticklish Subject: The Absent Centre of Political Ontology. Lond 